\title{
ANALYSIS OF THE PRACTICE OF CORRUPTION IN ELECTRONIC PROCUREMENT SERVICE SYSTEM IN THE KEPULAUAN RIAU PROVINCE
}

\author{
Rendra Setyadiharja 1) *, Achmad Nurmandi 2), Suyito ${ }^{3)}$ \\ ${ }^{1}$ Goverment Science Department of STISIPOL Raja Haji Tanjungpinang Raja Haji Fisabilillah \\ Road No. 48 Tanjungpinang-Kepualauan Riau, Indonesia. \\ 2 Director of Postgraduate Program Universitas Muhammadiyah Yogyakarta South Ring Road, \\ Bantul-Yogyakarta, Indonesia. \\ ${ }^{3}$ Sociology Department of STISIPOL Raja Haji Tanjungpinang Raja Haji Fisabilillah Road No. 48 \\ Tanjungpinang-Kepualauan Riau, Indonesia. \\ * Korespondensi Penulis. E-mail: rendra tanjungpinang@yahoo.co.id, Telp: +6281268660986
}

\begin{abstract}
Procurement of goods and services in Indonesia has carried out a number of reforms, ranging from conventional forms filled with indications of bribery and corrupt, now converted into a system of procurement of goods and services electronically with Electronic Procurement Service Systems (LPSE). Expectations the central government and local government is to minimize the occurrence of graft, a fictitious project, markup or transactional in the procurement of goods and services, but also LPSE system has never been separated from the threat of any indication of corruption in the procurement of goods and services. The purpose of this research is to know how corruption practices on the procurement of goods and services at Electronic Procurement Service in Kepulauan Riau Province. The method used was the exploratory qualitative approach. Data collection method used is by interview (indebt interview). Interviews were conducted with several informants, namely Kepulauan Riau Province Electronic Procurement Service (LPSE), Kepulauan Riau Province Procurement Service Unit (ULP), Kepulauan Riau Province Development Administration Bureau, and Provider of Goods and Services. The results of this research are descriptions of cases of corruption in the LPSE system in Kepulauan Riau Province, and the mode of operation corruption practices that occur in the LPSE system in Kepulauan Riau province.
\end{abstract}

Keywords: Corruption, Procurement, Electronic Procurement Service Systems (LPSE) 


\section{Jurnal Ilmu Pemerintahan, 2 (2), Oktober 2017 - 136}

Rendra Setyadiharja, Achmad Nurmandi, Suyito

\section{BACKGROUND}

Corruption is very familiar to indonesian people as there are so many corruption cases from central to regional. There are various cases such us bribery, dividend, cheating, incompetent official until money laundry which are involved ministry, chief of political party, the region head, business partner and civil.

Indonesia is in critical condition based on its corruption index. International Transparency Data of 2012 stated that Corruption Perception Index of Indonesia is 3,2\% that takes place in 118 of 176 country in the world which means Indonesia is still far behind other Southeast countries such as Singapore index 8,7; Brunei Darussalam index 5,5; Malaysia index 4,9; Thailand index 3,7; and Philiphina index 3,4 (Rofikoh and Noor, 2014).

One of the sectors which mostly contributed to corruption cases is procurement of goods and services sector. Of the few cases ever handled by the corruption eradication commission ( kpk ) during the year 2010-2011, $80 \%$ of cases of corruption related to procurement of goods and services (kpk report of 2011 in rofikoh and noor, 2014). Likewise, reports business Competition Supervisory Commission (KPPU) has more than $50 \%$ cases concerning collusion in the procurement of goods and services conducted by way of markups, collusion and manipulation of procurement seems to be something that is reasonable and can be found at every level of government to sector procurement of goods and services, the allocation of rp 450 trillion , $30 \%$ of them experienced leaks that every year the state leaking money reaches rp 100 trillion (LKPP report of 2011 in rofikoh and noor, 2014).

Based on the data from indonesia procurement watch survey which is reported to the corruption eradication commission (kpk) on march 2011, it is found $89 \%$ of government goods and services supplier do bribery (Setyadiharja et al., 2014). Because there are so many corruption cases occur in that sector, the indonesian government tries to find the solution to eradicate or at least decrease it. Therefore, the government makes a policy by changing the procurement of goods and services into electronic which is called e-procurement.

The government of Indonesia republic through the presidential regulation no 54 of 2010 about the procurement of goods and services which is completed in the second change of presidential regulation no 54 of 2012 about procurement of goods and services, then the government of the republic of indonesia expressly mandates the use of e-procurement system in the procurement of government goods and services . E -procurement that in principle is to change the mindset, of things that are manual and prone to abuse into an electronic system that reduces systemic face to face, so that misuse will be reduced(Setyadiharja et al., 2014). In addition, e-procurement is a tool to create governance that is free from corruption and nepotism, baed on the benefits of eprocurement is the shorter process, especially in terms of time, and bureaucracy, as well as cost savings in the procurement process Yakobus Tefa, 2013).

One of the region that carry out the e-procurement system in indonesia is 
kepulauan riau province. The adoption process began with the enactment of governor regulation 5, 2008 on guidelines for procurement of goods / services in electronics in the government of kepulauan riau province issued on march 12,2008 , and this regulation is published as a basic step implementation of eprocurement in this province (Setyadiharja et al., 2014). In a study of eprocurement in kepulauan riau province since the implementation in 2008 to 2014 , the e-procurement system is considered very effective rated with a score of 3.27 effectiveness index (Setyadiharja \& Nurmandi, 2016). The indicator is considered effective in these studies is the clear goal of the policy of eprocurement system and the type of website owned (Setyadiharja et al., 2014). Besides, the implementation of eprocurement system in kepulauan riau province have also been able to effectively and efficiently assessed in terms of the budget with an efficiency rate 3-13 \% in the period 2008-2012 (setyadiharja, 2014).

With the effectively assessment against the implementation of e-procurement system in kepulauan riau province, coupled that e-procurement system has been able to effect and streamline the government's budget, and whether corruption will also be reduced from the amount of corruption that often occurs in the procurement of goods and services conventional. Or e-procurement system would be tantamount to procurement of goods and conventional services that have always accounted for corruption, would bribe, markup, procurement fictitious, competition unfair business is still going on with the procurement of goods and services that have made use of this information technology.

Hence, this study will reveal the ratings the implementation of eprocurement system in kepulauan riau provinces considered to be very effective, there are still going on or not corruption in the procurement of goods and services, but it also will reveal how the practices of corruption happens with the system technology is considered rigid and stiff

\section{E-Procurement Concept}

Generally, e-procurement is the electronic process of goods and services purchases that is needed by an organization (oliviera in purwanto, ibty, rofikoh and indroyono,2008). General explanation of e-procurement system was applied system to the integrated database system from a large area of internetbased network communication system in a part of the entire purchase process (Croom, Brandon Jones in Purwanto, Ibty, Rofikoh and Indroyono, 2008). Mind and Galle's (Purwanto, Ibty, Rofikoh dan Indroyono, 2008) explain e-procurement as "business to business purchasing practice that utilizes electronic commerce to identity potential of supply, to purchase good and services, to transfer payment and to interest with supplier".

The difference between eprocurement and conventional procurement of goods and services has been explained by mitchell (purwanto, ibty, rofikoh and indroyono,2008) that is "traditional procurement is a paper based process that is characterized by fragmented purchasing, of contract buying and lack of control of expenditure, e-procurement facilitates, integrated, streamlines the entire supply chain 


\section{Jurnal Ilmu Pemerintahan, 2 (2), Oktober 2017 - 138}

Rendra Setyadiharja, Achmad Nurmandi, Suyito

process (from consumer to supplier and back again) in a seamless, realtime, and iterative manner".

There are some benefits of eprocurement system utilization that is explained by Neef (Purwanto, Ibty, Rofikoh and Indroyono,2008) as follows:

1. Low-cost transaction

2. Faster order

3. More vendors to choose

4. More efficiently procurement goods by standardized process

5. Better control on procurement goods dismissal and good official

6. More access internet for buyers

7.Less paper and decrease administrative procedure

8. Helping in rearrange of procurement goods process

The phases of e-procurement of goods and services via website explained by (setyadiharja et al., 2014)as follows :

1. Auction notification from the committee

2. Upload auction document by the committee

3. Download auction document by the committee

4. Auction explanation

5. Registration for offer document by the supplier

6. Commencement of offer document by the committee

7. The winner evaluation

8. Rebuttal to Official Commitment Maker

\section{Corruption Concept}

Corruption is from latin lagrange "corruption atau corruptus" that is copied to many languages such as in dutch 'corruptie' which means badness, rottenness or honest (Amiruddin, 2012). According to lopa (Setyadiharja et al.
2014) corruption "is a criminal offense relating to bribery and manipulation acts and other acts which harm or may harm the financial economic state, detrimental to welfare and interest of people". While brooks (Muis, 2010) states that corruption is deliberately making mistakes or dereliction of duty were unknown, so the obligation or without the right use of power, with the purpose of gaining profit more or less private. States that corruption is same with monopoly power plus discretion by officials minus accountability (Klitgaard, 2002). It means corruption is monopolized and strengthen power by official deviation without accountability action (Klitgaard, 2002).

Based on the corruption research by Alatas (Syamsudding, 2007) in Asia, especially in Indonesia and Malaysia, there are types of corruption, as follows:

1.Transactive corruption is money shows the deal between two sides who take and give benefits, both of them are doing it actively.

2. Extortion corruption is type of corruption where the giver side is forced to bribe to prevent loss for itself, the importance, people or other precious things.

3. Investive corruption is giving goods or services without directly connecting with certain profit, beside the future profit. This kind of corruption is done by the one who give money monthly to the judge by hoping the judge will process his/her case as soon as possible.

4. Nepotism corruption is illegal appointment to friends or family members to be official or prioritization 
of actions in all forms as opposed to the norm or regulation.

5. Defensive corruption is made by a victim of extortion, thus oppressed corruption to save its interests, corruption is usually done by the defendant's family who does not want the defendant detained or processed further.

6. Corruption autogenic is corruption by himself because they have the opportunity to take advantage of something known to himself

7. Corruption support is support for the existing corruption or the creation of an atmosphere conducive to doing corruption, corruption is carried out by an elite instituted judiciary does not have the political will to crack down subordinates.

In the context of corruption in the procurement of goods and services electronically there are several patterns of irregularities that are key to the occurrence of corruption in the procurement of goods and services electronically, as described by (Yakobus Tefa, 2013) and (Amiruddin, 2012) as follows :

1.The pattern of irregularities that occurred during the preparation is inflation (mark-up) costs in the procurement plan, particularly, in terms of cost, these symptoms can be detected from the unit price is unrealistic and Swelling number of APBN/APBD

2. The procurement plan is focused on the interests of certain products or providers of goods and services, specifications and criteria leads to a product and provider of certain goods and services, which can not be done by providers of other goods and services

3. Unrealistic planning, particularly from the point of execution time.

4. The committee works closely, honest and it seems like controlled by someone.

5. Own estimates the price overview (HPS) is covered up when it should not be confidential,

6. Unstandarized basic price.

7. Specification leads to a certain product

8. Unstandarized auction document

9. Uncomplete auction document

Then, Tefa (2013) and Amiruddin (2012) explain more about deviation pola in e-procurement of goods and services process as follows :

1. Short time notification

2. Uncomplete and flustered notification

3. Flawed document spread

4. Limited information by the committee and only certain side get it completely

5. Aawijizing is changed into ask and answer

6. Efforts to deter entry by certain elements of the tender document specified that the participants are late in submitting its bid documents

7. Replacement of documents is done by inserting a revision of the document in the initial document

8. The committee works closely.

9. Only certain side is announced the tender winner.

10. Not every rebuttal is answered,

11. Fulfillment letter is intentionally postponed so that they will receive money.

The discussion result of data secunda on many KPK reports which are 
explained in a research of rofikoh and noor in procurement goods and services process, it often occurs internal and external collusion that describe in the picture above :

Picture 1. Corruption Portrait in Procurement Goods and Services

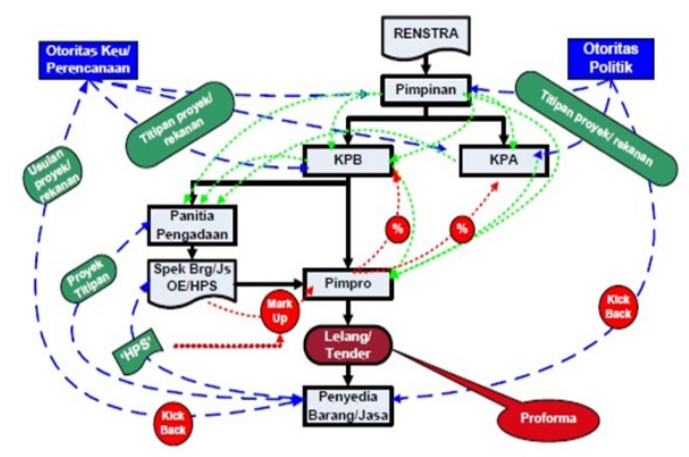

Source: KPK Report of 2012 in Rofikoh and Noor, 2014

In that picture, Rofikoh and Noor (2014) explain that one of operation modus of collusion/nepotism with outside agencies such as the projects "carried" by private parties/potential partners, as well as surrogate elements of political authority and financial authorities/planning also entrust the project/certain partners.

Besides the appointment of the procurement committee and leader of the project is not carried out on the basis of professionalism and integrity, but rather is based on the proximity of certain kinship between the leaders of institutions and employees concerned to meet the expenses granted as project leader (KPK Data in 2008 in Rofikoh and Noor, 2014)

\section{Research Method}

This research is an explorative research with a qualitative approach, which seeks to disclose all matters relating to corruption in the procurement of goods and services with e-procurement system in the Kepulauan Riau Province. Data Collection Techniques done by indepth interviews conducted on Unit Electronic Procurement Service (LPSE) Kepulauan Riau Province, Procurement Services Unit (ULP) Kepulauan Riau Province, Kepulauan Riau Province Development Administration Bureau and also providers of goods and services that had been involved in the procurement process of goods and services with eprocurement system in the Kepulauan Riau Province. In addition, data was also collected from secondary data through a review of literature relating to corruption in the procurement of goods and services with e-procurement systems.

FINDING AND DISCUSSION

Analysis of The Practice Of Corruption In Electronic Procurement Service System In The Kepulauan Riau Province

1. Corruption Cases with Opportunistic Legislative Behavior Mode in Procurement Planning

In Kepulauan Riau Province, it is found that there are some fraudulent cases in implementing e-procurement system which is caused by certain people who try to use the unperfect system of eprocurement. It is a suspicion that some parliament or legislative members become part the game.

A case happens in the Opening and Road Ossification Project of Tanah Kelarik in Teluk Buton which involve one of Kepulauan Riau Province legislative members who introvert the construction project for Rp. 6,9 billion which is on by PT Putera Bentan Karya. 
The opportunistic legislative behavior mode, in this case, is supposed that the legislative member adds Rp. 2 billion from the early project cost for Rp. 4 billion (Info Nusantara Newspaper, October 29, 2012). It is cleared by the interview result of the member about the case :

"In the early process, there was only Rp. 4 billion but when the discussion was going on, there was a suggestion to add it about Rp. 2 billion and it becomes Rp. 6 billion in the end. He said that it is agreed by the others" (Info Nusantara Newspaper, October 29, 2012)

The decision of adding the cost influences the winner of the project. PT Natuna Jaya states that there was intervention from a legislative member that makes PT Putera Bentan Karya wins the tender (Info Nusantara Newspaper, October 29, 2012).

\section{Picture 2. Auction Winner List of Jalan Kelarik Ossification Project}

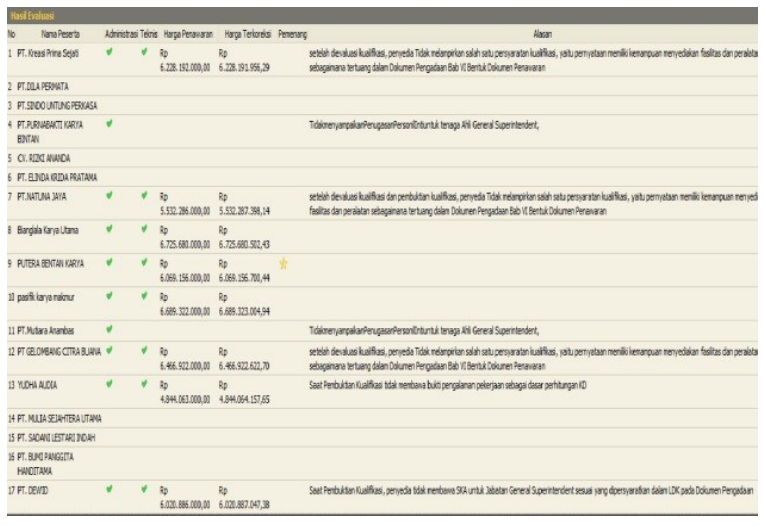

Source: www.lpse.kepriprov.go.id: 2013

In the picture above, it is showed that PT Putera Bentan Karya is the winner of the tender and PT Natuna Jaya is one of the participants to win the project.

In the rebuttal letter copy, No 02/SGH-NJ/V/2012, on 3rd Mei 2012, is written PT Natuna Jaya state to the Governor of Kepulauan Riau Province, that they conduct an appeal, once replying to answer refutation of the Working Group 2 ULP (Procurement Service Unit) Kepulauan Riau government, No 07/JWB-SGH/POKJA2ULP/APBD-04-2012, on 26th April 2012 or 27th April 2012, LPSE server time.

Furthermore, PT Natuna Jaya filed an appeal with a few things. The first point, Working Group 2 ULP has done irregularities provisions and procedures stipulated in Presidential Decree Number 54 The year 2010 concerning Procurement of Government Goods and Services. Because, based on procurement documents, summarized some of the stages of evaluation, namely: evaluation of the administrative, technical evaluation, price evaluation, qualification and final evaluation, verification of qualifications. So that bidders do not pass one phase alone is not able to follow the next stage.

The second point, PT Natuna Jaya had undergone the qualification proof (proof of qualification in accordance invitation number 05A/UND/POKJA2/ ULP/APBD-4-2012/P03), or pass the evaluation stage before, marked the final stage, proof of qualification are qualified.

On the website LPSE Kepulauan Riau Province, PT Natuna Jaya did not win the tender because, after an evaluation, qualification, and verification of qualifications, the company did not attach one qualification that ability of facilities and equipment supplying statement

The deviation of victory PT Putera Bentan This work subsequently been submitted to the State Administrative High Court (Administrative Court) Terrain (Newspaper General Info Nusantara dated October 29, 2012). 


\section{Jurnal Ilmu Pemerintahan, 2 (2), Oktober 2017 - 142}

Rendra Setyadiharja, Achmad Nurmandi, Suyito

This case also reap other problems when its implementation in the field, as reported by the Newspaper General Info Nusantara dated October 29, 2012 reveals some irregularities course of the project among other projects along the 7 $\mathrm{km}$ and $2 \mathrm{Km}$ not do land clearing, shift the roads are not discussed with local residents and do shifting the roads are not in accordance with the initial planning to the detriment of society. While the alleged irregularities in the field are due to the intervention of the North Head Bunguran in this project.

The case is when analyzed further as a result of early intervention in the procurement process with the conduct that led to the opportunistic attitude of the legislature that is by adding a budget amid the course of the process and not the beginning of the budget. Then followed again by winning of PT Putera Bentan work improperly. This certainly invites a diverse interpretation. Legislative procedural error adding the budget of the initial budget are indications of legislative intervention in the determination of the winning bidder. Although there is agreement among the board, the addition of the initial budget is considered a procedural manner that is not related to the budgeting process. So that, in this case, the legislature deemed to have violated several laws related to the budget process.

The intervention of the legislature is still in the implementation of eprocurement system in Kepulauan Riau Province, causing few deviations. This is as the result of an interview with one of the owners of providers of goods/ services involved in e-procurement system in Kepulauan Riau Province following:

"When the auction process, the board would approach the Working Group that is in the ULP to facilitate the approach to the LPSE and knowing the work being tendered working group which, in the remainder of LPSE usually board will affect the Chairman LPSE and will continue in effect Chairman LPSE to the verifier, later verifier will facilitate partners who already is a surrogate of the board was to participate in the tender process in the system in LPSE, usually this is where the game, all documents have been given and gives a chance for the company to this deposit enter and win in the bidding process without seeming a deposit, then the process is still enforced the rules and systems LPSE but there is connivance in advance at the start of the auction process, in which all document gives a chance to win. So the company entrusted this council could win the tender "(Interview with PT Anugrah Jaya Date October 31, 2013).

Intervention by the model as described above, which led to the victory of several companies that are considered unnatural for their game or backing of the legislature. This was confirmed also by the results of interviews with providers of goods/services, as follows:

"Games in the e-procurement can happen when a company partner approached the PA, the PKK, and PPTK, then called on the powers of the council as an amplifier, then they will approach the task force which in ULP conducting auctions, and together with their councils would affect LPSE order to won a job tendered (Interview with PT Sinergy Visi 
Utama Representative Tanjungpinang, November 9, 2013).

Legislature with the power and authority sometimes opportunistic in the process of implementing e-procurement system with the interventions, of course, talking a matter of interest. Legislative opportunistic behavior can be explained in the following pattern :

Picture 3. Legislative intervention pattern in E-Procurement System Implementation in Riau Islands Province

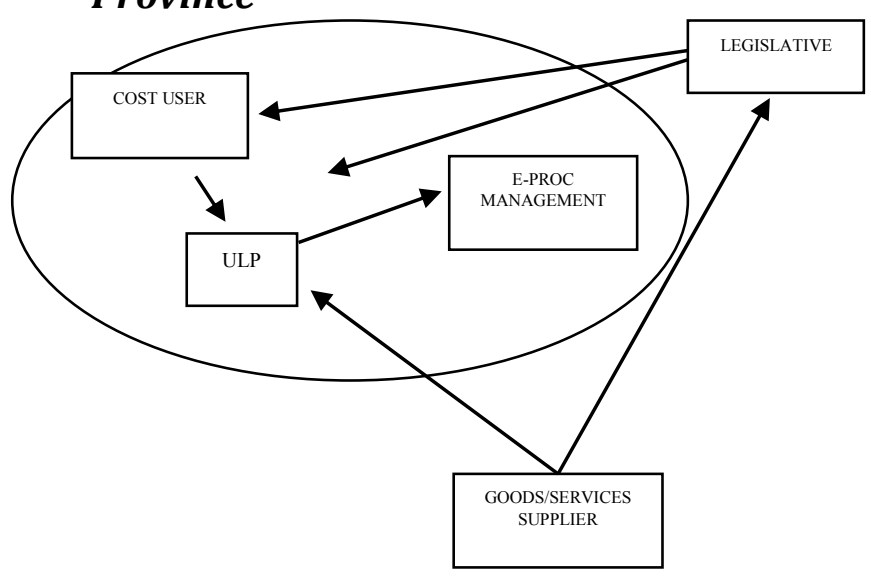

In the picture above, it appears that the legislature was also under pressure from providers of goods/services is political, even more, providers of goods/services are the constituencies that have contracted with the politics of certain legislative.

This is where the provider of goods/services have a political way in influencing the procurement process as lobbying the legislature (Thai, 2008). Providers of goods/services will also be lobbying the Procurement Services Unit (ULP) with the authority and have the auction what information will be processed in a specific financial year. However, to participate in the auction process, he must follow the procedures through a process that has been set up with e-procurement systems are implemented technically by LPSE. To smooth the auction process, then the provider will approach the legislature that is politically closeness and relationships. This is where the legislative opportunistic behavior occurs, either to the intervention process of a budget user who has the authority of a general procurement plan and also to the ULP has the authority elections goods/services provider, set the procurement documents to assess the qualifications of providers of goods and services. The hope is that by intervening in the Budget User legislative tender already know what will be auctioned in the fiscal year through public procurement plan. Furthermore, by intervening ULP, the legislature hopes that providers of goods/services "surrogate" legislative will win eventually. With the hope of further intervention is requested ULP regulate all the processes in LPSE that providers of goods/services "surrogate" legislative win according to the procedure.

Interventions that occur as this will lead to corruption. In a study conducted by Arnaiz (Thai, 2008) explains that the corruption in the procurement of goods/services could reach an average of 15-30 percent of the total budget. This often happens because the legislature usually asks for a project for the benefit of their constituents or their electoral districts ( Robinson in Thai, 2008). On that basis, the legislature did opportunistic attitude so that their interests can be achieved. Opportunistic attitude form of intervention in the eprocurement process can cause corruption in the form of bribery, business or game insiders as well as 
abuse of authority (Nugroho, 2006), where the research generated a lot of leaks of state budget and things like this which could damage the e-procurement system aimed at reducing indications of corruption.

The intervention of the legislature is still felt there was the implementation of e-procurement system in the province of Riau archipelago LPSE. But Riau Islands provincial government also has very strict about this, the possibility of irregularities that may exist, but to prevent it DPRD Kepulauan Riau Province has firmly told to return all the pressure and opportunistic behavior that occurs on the rules and regulations that have been set. As explained by the Deputy Chairman of III DPRD Kepulauan Riau Province as follows

"Providers may exist who want to lobby, but usually occurs in Musrenbang, but keep going back to the applicable procedures. Perhaps there is lobbying strongly affirm but the council must pass a professional procedure and integrity have been created. In principle, anyone entitled to participate in the eprocurement project as long as it can be professional and integrity, all of this in order to achieve a good purpose of eprocurement "(Interview with Vice Chairman III DPRD Kepulauan Riau Province Date 28 November 2013)".

Kepulauan Riau Provincial Parliament's commitment to the optimal implementation of e-procurement system is so strong that strongly affirm that all forms of opportunistic behavior either from providers of goods/services or the legislature itself then return it to the regulations and rules that have been set. DPRD Riau islands are sure the e- procurement system in Kepulauan Riau Province is very strict, and if there is pressure, and the game was the return to the rule. This is as written by the Vice Chairman of III DPRD Kepulauan Riau Province based on the interview below:

"The implementation of the system is highly protected by the rules, mechanisms have been set, and if you get pressure it must return to the applicable rules and should not be ignored such pressure. In the procurement, a mechanism should see a proportional manner and in a professional manner, so that no problematic projects in the future "(Interview with Vice Chairman III DPRD Kepulauan Riau Province Date 28 November 2013).

Not only from the Riau Islands Provincial Parliament who has a commitment to any pressure or opportunistic behavior that occurs returned to the applicable rules, Head of Development Administration Regional Secretariat of the Kepulauan Riau Province also said the same thing as the result of the interview follows:

"Political pressure is still there, but the decision to political pressure and other interests returned to the applicable rules" (Interview with Head of Development Administration Regional Secretariat of the Kepulauan Riau Province Date of December 2, 2013).

Thus it can be seen that the opportunistic behavior legislature in the implementation of e-procurement system in LPSE Kepulauan Riau still exist, but strongly either DPRD Kepulauan Riau Province and Local Government through the Bureau Chief Administrators Development Regional Secretariat of the Kepulauan Riau Province stipulates that 
any pressure and opportunistic behavior of the legislature should be returned to the regulations, rules, and procedures have been established.

This commitment has also been demonstrated that the results of respondents in this study considered that the regulation is considered very effective in the implementation of e-procurement system in Kepulauan Riau Province, and with the regulation that is very effective is the Provincial Government of Kepualaun Riau boldly and decisively to restore all the pressure, intervention and games that lead to deviations in the regulations, rules, and procedures have been established.

The political commitment of the Regional Government whether it DPRD Kepulauan Riau Province or the Bureau of Development Administration Regional Secretariat of the Kepulauan Riau Province is an attitude that is very wise to restore all the interventions, pressures and games that will hurt the eprocurement system with the regulations, rules, and procedures have been established, It is as stated by (Thai, 2008), that it takes a compromise between the government (legislative and executive) and also the interest to create a proper system in the procurement process, and the Government of Kepulauan Riau Province has made eprocurement system is good and keeping with a commitment to the regulations, rules, and procedures have been established.

\section{Corruption Case with Game Mode Contracts and Deviance Information}

Significantly it is the determination of the contract or the winner has done well by LPSE Kepulauan Riau Province and ULP. If the prism of the previous parameters, that the information provided has been very clear, including the determination of the winning bidder is shown on the website LPSE Riau Islands Province. But sometimes behind the system is still finding irregularities due to the influence of the political process in the form of pressure. Indeed, the real e-procurement system in both LPSE and ULP Kepulauan Riau Province has the system well. However, there are some cases, they just happen to missed ensued system so that irregularities in the implementation of e-procurement system in the Riau Islands. cases that lead to action deviation is also influenced by infrastructure and network are still not optimal, human resources is also not an employee of permanent employees in LPSE Kepulauan Riau Province and also in ULP Kepulauan Riau Province is also still an employee related SKPD sometimes the system is already well may be compromised because some of these shortcomings.

An online media in Kepulauan Riau Province(bakinnews.com, February 4, 2012) to get a case of irregularities in the procurement process of goods/which indicated that the collusion between providers of goods/services to the Working Group (WG 2) Procurement Services Unit (ULP) Kepulauan Riau Province. Periodic road maintenance projects Batam Batam city center which is worth 4.9 billion won by PT patens Agriutama as indicated in the announcement of winners on the website following LPSE Riau Islands Province. 
Picture 4. Winners List Auction on Periodic Road Maintenance Project Batam Center, Batam City

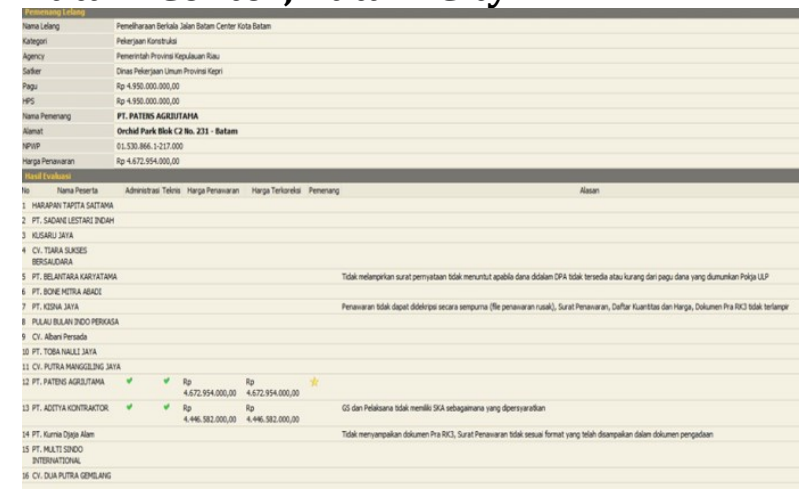

Source: www.lpse.kepriprov.go.id: 2013

In the image printed the name of the winning bidder company is PT patens Agriutama. But this victory was alleged collusion between providers of goods/services to the ULP. Some deviations can be seen from the things described by bakinnews.com (bakinnews.com, February 4, 2012) the following:

1. Evaluation of bids also occurred on October 30, 2012, This is a thing that does not make sense because it happens the same time with the opening of the tender document,

2. Upload the results of the auction news 1 November 2012 and the determination of the results of the winners of November 1, the tender project was announced on October 22, s/d.25 October 2012, but the announcement was not on the schedule, but there is the internet, the severity of the schedule cannot be open. Download procurement document dated October 22, s/d October 29, 2012, but could not be downloaded. Giving explanations contained in the schedule on 24 October, but nothing is done. Upload offering document dated October 25 , s/d October 30, could not get uploaded.

3. The opening of offer document dated October 30, 2012, was never carried out. November 2012 was not released on the internet. Objection period November 7, 2012, no proper internet 5-day objection period. Deals appointment letter dated 12 November 2012. There is an indication of the kickbacks PT. Patent Agriutama to WG-2 at $2.5 \%$ of the value of deals.

With some of the above problems, it is rated the indication game occurred in the implementation of the e-procurement system. The project is expected to have violated Law No. 5 of 1999, which has occurred in unfair competition vertically and horizontally, WG 2 has been deemed not transparent and deliberate cover-up electronic auction schedule. Modus is a procurement committee, which in this case is the Working Group 2 ULP Kepulauan Riau Provincedeliberately cover up the information for other companies. So several stages as time evaluation of bids allegedly unreasonable because it coincides with the opening of the bidding documents, the download process is difficult for providers of goods/services other, upload documents and announcements cannot be accessed by providers of goods/services other, and followed by absence objection period that should be given as long as five days. From the vagaries of the mechanisms and stages of this, rated indications of the procurement committee want to win a particular party in this project. The mechanism for determining the winner of the contract or that happens deliberately obscured from providers of 


\section{Jurnal Ilmu Pemerintahan, 2 (2), Oktober 2017 - 147}

Rendra Setyadiharja, Achmad Nurmandi, Suyito

goods/services other in the hope of goods/services that have approached the committee in providing or no goods/services provider who wants to be won by the procurement committee.

The case of the procurement committee deemed to have violated several articles of Law No. 5 of 1999 on Prohibition of Monopolistic Practices and Unfair Business Competition, which allegedly procurement committee has done a covered agreement or collusion with the goods/services provider certain to win a purchase so that providers goods/services other could not compete fairly in the purchase. But the case has yet to be proven clearly from the deviations that occur above, and now the project has been completed tendered.

This deviation is a real form which is evidence that the mechanism or the award of the contract still contained pressure and intervention in the implementation of e-procurement system in LPSE Riau Islands Province. It is actually an old pattern of behavior with which still exists on the person who wants to destroy the system, while the system was designed very well by the Provincial Government of Riau Islands. Most cases of corruption and irregularities in the domestic procurement of goods/services occur when elections supplier of goods/services (Arnaiz in Thai, 2008). Most cases are their games and collusion with government officials, or the backing of legislative, and this is what happened in the case described above (Arnaiz in Thai, 2008).

As explained in the previous discussion on the parameters of the legislative opportunistic behavior, was found to be the intervention of any legislative or provider of goods/services in the e-procurement system. However, interventions or pressure that are difficult to prove clearly remember the company that won the tender are listed on the website LPSE Kepulauan Riau Province with clear and able to be seen by all parties.

But the government's attitude good DPRD Kepulauan Riau Province and Head of Development Administration Regional Secretariat of Kepulauan Riau Province is very firm, as explained in the previous discussion stating that if there is pressure, then the procurement management are asked to bring in regulations, rules, and procedures. This attitude is an ideal form in which the Regional Government of Kepulauan Riau Province realize that the function of regulation, the rules and procedures established a regulator and controller systems from a variety of deviant behavior as described by (Schapper, Malta, \& Gilbert, 2006) that the regulation was designed with robust and high commitment in an e-procurement system is to minimize unwanted discretion.

\section{CONCLUSION}

In the implementation of $\mathrm{e}$ procurement system, there are several aspects that need to be monitored, such as regulation, infrastructure, and human resources. Because of the elaboration of the above two cases, it can be concluded that the behavior of corruption in procurement systems of $\neg$ e-occur due to human resources that are not consistent in their enforcement of regulation, then the weakness of infrastructure, causing the gap to their deviant behavior. With 


\section{Jurnal Ilmu Pemerintahan, 2 (2), Oktober 2017 - 148}

Rendra Setyadiharja, Achmad Nurmandi, Suyito

the weakness of these three variables, the opportunistic behavior will be formed and it will create a case of corruption in the procurement of goods and services in the e-procurement system.

Then, in addition to the contractual mechanisms and procedures that run should really do a watchful eye, because this is one of the doors to cheating in the procurement of goods and services, especially with e-procurement system.

Hence, for local governments who adopt e-procurement system, must first improve the commitment which is then translated into regulations that will keep the implementation of an e-procurement system. Then strengthen infrastructure such as information technology systems, strengthen human resource capabilities, and provide a positive understanding of the providers of goods and services, all of it must be a robust system that does not happen more severe irregularities in the e-procurement system.

\section{DAFTAR PUSTAKA}

Amiruddin, A. (2012). Analisis Pola Pemberantasan Korupsi Dalam Pengadaan Barang/Jasa Pemerintah. Jurnal Kriminologi Indonesia, 8(1). Diambil

Dari Http://Journal.Ui.Ac.Id/Jki/Article/Vi ew/1078

\footnotetext{
Klitgaard, R. (2002). Penuntun Pemberantasan Korupsi Dalam Pemerintahan. Yayasan Obor Indonesia. Diambil Dari Https://Www.Google.Com/Books?Hl $=I d \& L r=\& I d=D 2$ vocufe3_Ec\&Oi=Fnd $\& \operatorname{Pg}=\operatorname{Pr} 11 \& \mathrm{Dq}=$ Klitgaard, + Robert. +( 2002).+Penuntun+Pemberantasanko rupsidalam+Pemerintah+Daerah.+Jak arta:+Yayasan+Obor+Indonesia.\&Ots $=$ Nkf9e3nqcw $\&$ Sig=Ecuggfqocu 4 ul2p h-F-Dkdpsoku
}

Nugroho, R. A. (2006). Studi Penjelajahan Tentang Kebijakan Pengadaan Barang/Jasa Melalui Internet Di Departemen Pekerjaan Umum. Spirit Publik, 2, 75-80.

Schapper, P. R., Malta, J. N. V., \& Gilbert, D. L. (2006). An Analytical Framework For The Management And Reform Of Public Procurement. Journal of Public Procurement, 6(1/2), 1.

Setyadiharja, R., Budiman, S., Karim, Z. A., Matridi, R. A., Nurmandi, A., \& Others. (2014). E-Procurement System Technology: An Analysis In Electronic Procurement Service Unit (Lpse) Of Kepulauan Riau Province. The Asian Journal of Technology Management, $7(2), 93$.

Setyadiharja, R., \& Nurmandi, A. (2016). Implementasi Sistem E-Procurement Pada Layanan Pengadaan Secara Elektronik (Lpse) Provinsi Kepulauan Riau. Journal of Governance And Public Policy, 1(2). Diambil Dari Http://Journal.Umy.Ac.Id/Index.Php/ Gpp/Article/Viewfile/2105/2032

Thai, K. V. (2008). International Handbook of Public Procurement. Crc Press. Diambil Dari Https://Www.Google.Com/Books?Hl $=I d \& L r=\& I d=L z g x h y m i q u i c \& O i=F n d$ $\& P g=P p 1 \& D q=$ Thai, + Khi.V.+(2009).+ International+Handbook+Of+Public+ Procurement.+Usa:+Taylor+And+Fra ncis + Group \&Ots $=$ Qpbbcb76jv\&Sig $=D$ vzkukfqjv4dbiggblwyuwswe $3 \mathrm{~m}$

Yakobus Tefa, S. A. (2013). Korupsi Dalam Pengadaan Barang/Jasa Secara Elektronik Corruption In The Electronic Government Procurement. Jurnal NESTOR Magister Hukum, 2(4). 


\section{Jurnal Ilmu Pemerintahan, 2 (2), Oktober 2017 - 149}

Rendra Setyadiharja, Achmad Nurmandi, Suyito

\section{PROFIL SINGKAT}

\section{RENDRA SETYADIHARJA, S.Sos., M.IP}

Born in Tanjungpinang on March 20, 1986, is a lecturer at the Stisipol Raja Haji Tanjungpinang Kepulauan Riau. Completed primary education at SDN 003 Tiban Batam (graduated in 1999), then continued to Madrasah Tsanawiyah Negeri Tanjungpinang (graduated in 2002), then continued his senior high school education at SMA Negeri 1 Tanjungpinang (graduated in 2005). The author completes his undergraduate education at STISIPOL Raja Haji Tanjungpinang in Government Studies Program (graduated in 2010), then completes his master's degree in Magister Ilmu Pemerintahan Universitas Muhammadiyah Yogyakarta (graduated in 2014) with the predicate Cumlaude and Best student.

\section{Prof. Dr. ACHMAD NURMANDI, M.Sc}

Born in Belinyu, Bangka. Is a Vice-Rector IV of Cooperation and Internationalization of Muhammadiyah University of Yogyakarta. Graduated with a bachelor degree in UGM Faculty of Law Science Department in 1989, continued his master's degree in Urban Management Planning and Environment Management at Asian Institute of Technology, Bangkok Thailand in 2008, completing his Doctorate Degree in Public Administration of Universitas Indonesia 2011.

\section{SUYITO, S. Sos., M.Si.}

Graduated his bachelor degree in Stisipol Raja Haji Tanjungpinang, Sociology Study Program and graduated in 2006, continuing his Master's degree in Sociology at Andalas University and graduated in 2013. Currently as a Lecturer of Sociology Program of Stisipol Raja Haji Tanjungpinang and mandated as Head of Library Unit of Stisipol Raja Haji Tanjungpinang 